\title{
THE CORRELATION BETWEEN STRUCTURE AND $\beta$-NUCLEATION EFFICIENCY OF Ba, Sr, Ca AND Mg PIMELATES IN ISOTACTIC POLYPROPYLENE*
}

\author{
A. Janevski ${ }^{1,4, *}$, G. Bogoeva-Gaceva ${ }^{2,4}$, V. Stefov ${ }^{3,4}$, M. Najdoski ${ }^{3,4}$ \\ ${ }^{1}$ Faculty of Technology, University Goce Delčev, Krste Misirkov bb, 2000 Štip, Republic of Macedonia \\ ${ }^{2}$ Faculty of Technology and Metallurgy, Ss. Cyril and Methodius University, Ruger Bošković 16, \\ 1000 Skopje, Republic of Macedonia \\ ${ }^{3}$ Institute of Chemistry, Faculty of Natural Sciences and Mathematics, Ss. Cyril and Methodius University, \\ P.O. Box 162, 1001 Skopje, Republic of Macedonia \\ ${ }^{4}$ Research Center for Environment and Materials, Macedonian Academy of Sciences and Arts, \\ 1000, Skopje, Republic of Macedonia \\ *aco.janevski@ugd.edu.mk
}

\begin{abstract}
The pimelates of the earth-alkaline elements and pimelic acid have been synthesized and studied. All prepared pimelates are crystallohydrates and $\mathrm{Ba}$ and $\mathrm{Sr}$ pimelates are isotypic. The obtained compounds have been characterized using infrared spectroscopy and X-ray diffraction, and it was found that, near and above the melting temperature of polypropylene, the pimelates of $\mathrm{Ba}$ and $\mathrm{Sr}$ are crystalline, whereas the ones of $\mathrm{Ca}$ and $\mathrm{Mg}$ are amorphous. The nucleation activity of these pimelates has been studied in the process of crystallization of polypropylene in non-isothermal conditions and followed by differential scanning calorimetry (at cooling rate $V_{\mathrm{c}}=1-20 \mathrm{~K} \mathrm{~min}^{-1}$ ). It was found that their nucleation activity, even at concentration of $0.1 \%$, differs considerably with regards to the cooling rate, and they induce different polymorphic composition of the polymer. The nucleation activity was mostly exhibited by $\mathrm{Ca}$ pimelate, and when it was used the content of the $\beta$ crystalline phase $\left(U_{\beta}\right)$ in polypropylene ranged from 0.90 to 0.94 , depending on the cooling rate, compared to $0.18-0.35$ when $\mathrm{Mg}$ pimelate was used. In the polymer crystallized by using $\mathrm{Ba}$ and $\mathrm{Sr}$ pimelate as nucleators, $U_{\beta}$ ranged from 0.47 to 0.77 . Based on the theoretical concepts for nucleation activity of solid substrates, an attempt was made to correlate the structural features of the synthesized pimelates with their $\beta$-nucleation activity in the process of nonisothermal crystallization of iPP.
\end{abstract}

Key words: polypropylene; polymorphism; $\beta$-nucleators; pimelates

\section{КОРЕЛАЦИЈА ПОМЕЃУ СТРУКТУРАТА И $\beta$-НУКЛЕАЦИОНАТА ЕФИКАСНОСТ НА Вa, Sr, Са И Мg ПИМЕЛАТИ ВО ИЗОТАКТИЧЕН ПОЛИПРОПИЛЕН}

Синтетизирани и изучувани беа пимелати на земноалкални метали. Сите овие пимелати се кристалохидрати, а пимелатите на $\mathrm{Ba}$ и $\mathrm{Sr}$ се изотипни. Добиените соединенија беа карактеризирани со помош на инфрацрвена спектроскопија и рендгенска дифракција и беше најдено дека близу и над точката на топење на полипропиленот, пимелатите на $\mathrm{Ba}$ и $\mathrm{Sr}$ ce кристални, додека оние на Са и $\mathrm{Mg}$ се аморфни. Нуклеационата активност на овие пимелати беше изучувана со диференцијална скенирачка калориметрија со кристализација на полипропилен при неизотермални услови (со брзина на ладење $V_{\mathrm{c}}=1-20 \mathrm{~K} \mathrm{~min}{ }^{-1}$ ). Беше најдено дека нивната нуклеациона активност и при концентрации од 0,1 \% значително се разликува во зависност од брзината на ладење и се добива различен однос на полиморфните модификации на полимерот. Најизразена беше нуклеационата активност на пимелатот на Сa, а во случајот кога тој беше употребен, содржината на $\beta$-кристалната фаза $\left(U_{\beta}\right)$ во полипропиленот беше од 0,90 до 0,94 , во

\footnotetext{
- Dedicated to Academician Gligor Jovanovski on the occasion of his $70^{\text {th }}$ birthday.
} 
зависност од брзината на ладење, споредено со 0,18-0,35 кога беше употребен пимелат на $\mathrm{Mg}$. Во полимерот кристализиран со употреба на пимелати на $\mathrm{Ba}$ и $\mathrm{Sr}$ како нуклеатори, $U_{\beta}$ е од 0,47 до 0,77. Имајќ г ги предвид теоретските концепти за нуклеационата активност на супстратите, беше направен обид да се корелираат структурите на синтетизираните пимелати со нивната $\beta$ нуклеациона активност во процес на неизотермална кристализација на іРP.

Клучни зборови: полипропилен; полимофизам; $\beta$-нуклеатори; пимелати

\section{INTRODUCTION}

The overall properties of polypropylene (PP) are determined by its crystalline morphology, i.e. the amount of crystalline phase, crystal type, the thickness of lamellae, etc. Isotactic polypropylene (iPP) crystallizes into several crystalline modifications, such as monoclinic $(\alpha)$, hexagonal $(\beta)$ and triclinic $(\gamma)$ form, depending on the conditions of crystallization and molecular characteristics [110]. Thermodynamically the most stable $\alpha$ crystalline phase originates under common crystallization conditions that occur in industrial practice during manufacturing of different iPP-based products.

In the recent years $\beta$-iPP has attracted great scientific interest due to its unique characteristics that enable production of toughened plastic products, microporous membranes and fibers, thermoformed articles, pressurized pipe systems, etc. The $\beta$-form iPP exhibits lower strength but much higher impact toughness than the $\alpha$-form. A higher content of $\beta$-form in iPP can be achieved under specific conditions, such as rapid quenching of molten polymer, crystallization under a temperature gradient and/or shear stresses [11-16], as well as in the presence of selective $\beta$-nucleating agents [17-31]. In industrial practice of semicrystalline polymers, nucleating agents are used routinely to enhance the overall crystallization rate and thus, to shorten the production cycles, or to impart improved mechanical or optical properties by reducing spherulite size [31]. However, selective nucleating agents, both inorganic and organic, have been also developed for iPP to induce appearance of a certain polymorphic modification and to alter its crystal morphology.

The best known $\beta$-nucleating agents for iPP are the quinacridone pigment, pimelic acid/calcium stearate mixtures, calcium salts of suberic and pimelic acid [17], $\mathrm{CaCO}_{3}$ modified with dimeric aluminates, $N, N^{\prime}$-dicyclohexyl-terephtalamide, $N, N^{\prime}$ dicyclohexyl-2,6-naphthalene-dicarboxamide, etc. [19-21]. Also, different dicarboxylates have been tested as $\beta$-nucleators for iPP [17, 22-30], among which the Ca-salts of pimelic and suberic acids have shown high nucleation efficiency, while the
Al- and Cd-salts have been inactive in nucleation of PP [22, 23, 30, 31].

Several mechanisms and models of heterogeneous nucleation in crystallization of polyolefines, taking into account self-nucleation, and physical and chemical interactions involved in primary nucleation, have been developed. Among them, the model of epitaxial crystallization proposed by Lotz and Witmann [32, 33] is the most frequently used for polyethylene and polypropylene. According to these authors, the epitaxial growth of polyolefines proceeds on the nonpolar part of the molecule of the nucleating agent. It should be mentioned that the epitaxy of polymers on inorganic and organic substrates has been studied intensively by many authors [32-41]. Lotz and Witmann have analyzed heterogeneous nucleation in terms of physical interactions of the polymer and the nucleating agents. They have shown that, in the case of matching lattice sizes of the nucleator and the polymer, epitaxial growth of polymers on substrates occur, since the quest polymer chains lie with their chain axis parallel to the substrate surface [33]. In their extensive study of the nucleation of the $\alpha$-form of iPP [35] it was found that the matching lattice dimension is about $0.5 \mathrm{~nm}$ for most of the different active substrates, including various polymers, salts and other compounds. The interactions between the polymers and solid substrate surfaces (including polymeric surfaces, see for instance $[39,40]$ ) have been a subject of extensive research activities [34-41].

Mathieu et al. [35] have demonstrated that different nucleating agents which acted via different dimensional matching could interact with the same contact face (010) of iPP. Stocker et al. [36] observed the epitaxial growth of $\beta$-form iPP on the crystal of a nucleating agent. The results showed that the nucleating agent with about $0.65 \mathrm{~nm}$ periodicity and orthogonal geometry of the contact face could induce the $\beta$-form iPP crystals. Kawai et al. studied the alignment of the iPP crystals induced by $N, N^{\prime}$-dicyclohexyl-2,6-naphthalenedicarboxamide under a magnetic field [37]. Thus, it becomes clear that the selectivity of the nucleating agents can be evaluated by a dimensional lattice matching theory, central part to which is that a rea- 
sonable epitaxial match occurs between the repeat distance in the iPP unit cell and the corresponding nucleating surface.

As a conclusion, the epitaxial crystallization would occur when the requirement that crystallographically lattice matching, e.g. a coincidence of unit-cell dimensions, was achieved.

Despite the fact that some salts of pimelic acid have been shown to exhibit $\beta$-nucleation ability towards iPP, yet there are no published data concerning the characteristics of their active form and structural peculiarities in the course of crystallization process. On the other hand, there is only scarce information about the structure of pimelic acid salts, with exception of those published for Srand Ba-pimelates. Structures of strontium and barium pimelate monohydrates were solved using $\mathrm{X}$ ray powder diffraction data [42-44]. These compounds are isotypic and crystallize in the monoclinic crystal system (space group $C 2 / m$ ) with $Z=$ 4. Both isotypic compounds are built of layers of coordination polyhedra connected by pimelic acid molecules. It was found that the coordination mode of carboxylate groups is bridging tridentate and that only one crystallographic type of water molecules occupying $C_{\mathrm{s}}$ positions exists in the crystal structure which is located at two opposite vertices of each polyhedron.

Our goal in this work was the study of structural characteristics of $\mathrm{Mg}, \mathrm{Ca}, \mathrm{Ba}$ and $\mathrm{Sr}$ pimelates and their behavior in a temperature range of interest for processing of iPP (above $200{ }^{\circ} \mathrm{C}$ ). An attempt was made to correlate their structure with the $\beta$-nucleation activity in the process of iso- and nonisothermal crystallization of iPP.

\section{EXPERIMENTAL PART}

\subsection{Materials}

iPP homopolymer with $I_{\mathrm{i}}=0.94, \mathrm{MFR}=0.3$ $\mathrm{g} / 10 \mathrm{~min}$ at $230{ }^{\circ} \mathrm{C}$ and $21.2 \mathrm{~N}$ load, $\mathrm{Mw}=1069$ $\mathrm{kg} / \mathrm{mol}$ and $M_{\mathrm{w}} / M_{\mathrm{n}}=6.72$, is a product of Borealis, kindly donated by Polymer Bank of COST Action P12. Pimelic acid (analytical reagent) and carbonates of magnesium, calcium, strontium and barium were commercially available (Merck). Magnesium, calcium, strontium and barium salts of pimelic acid were synthesized by reaction of $50 \%$ $(\mathrm{m} / \mathrm{m})$ of pimelic acid with carbonates (analytical or chemical pure reagents). All synthesized pimelates were obtained as white powders with average grain size of $40-50 \mu \mathrm{m}$. $\beta$-nucleated iPP was obtained by mixing $0.1 \%(\mathrm{~m} / \mathrm{m})$ of pimelates with iPP in Brabender mixer PL 2000 at $460 \mathrm{~K}$.
The influence of annealing temperature on the microstructure was investigated by FT-IR and X-ray powder diffraction analyses on the samples of magnesium, calcium, strontium and barium salts of pimelic acid annealed in tubular furnace up to $250{ }^{\circ} \mathrm{C}$ for $1 \mathrm{~h}$ in air and atmospheric pressure.

\subsection{Differential scanning calorimetry (DSC) measurements}

Isothermal and nonisothermal crystallization of BNP was analyzed by DSC. In isothermal regime, the sample was rapidly heated to $478 \mathrm{~K}$ and held in the molten state for $5 \mathrm{~min}$, to erase the thermal history of the polymer. Then the sample was cooled to a given crystallization temperature, $T_{c}$ with a cooling rate of $80 \mathrm{~K} / \mathrm{min}$. Isothermal crystallization was carried out at $T_{c}$ until crystallization was completed. The crystallization under nonisothermal conditions was performed by cooling at different cooling rates: 1, 3, 5, 10, 15 and 20 $\mathrm{K} / \mathrm{min}$. The experiments were carried out with a Perkin Elmer DSC-7 analyzer under nitrogen and the calibration was performed with indium and zinc. The sample weight in all experiments was 7.0 $\mathrm{mg}$. Based on the determined values for the enthalpy of crystallization, the extent of crystallization (crystal conversion), $\alpha$, is calculated by equation (1).

$$
\alpha=\frac{\int_{0}^{t}\left(\frac{d H}{d t}\right) d t}{\int_{0}^{\infty}\left(\frac{d H}{d t}\right) d t}=f(t)
$$

The amount of $\alpha$ and $\beta$-phase iPP in model composites was calculated on the base of the corresponding melting enthalpies, using the following values: $\Delta H^{0}{ }_{\mathrm{m} \beta}=193 \mathrm{~J} / \mathrm{g}$ [45] and $\Delta H^{0}{ }_{\mathrm{m} \alpha}=209 \mathrm{~J} / \mathrm{g}$ [46-48]. The melting peaks of both polymorphic phases appeared well resolved on DSC thermograms (Fig. 1), enabling calculation of the amount of $\alpha$ and $\beta$-phase iPP by equations (2-4) [49, 50].

$$
\begin{aligned}
X_{\beta} & =\frac{\Delta H_{\mathrm{m} \beta}}{\Delta H_{m \beta}^{0}} \\
X_{\alpha} & =\frac{\Delta H_{\mathrm{m \alpha}}}{\Delta H_{\mathrm{m} \alpha}^{0}} \\
U_{\beta} & =\frac{X_{\beta}}{\left(X_{\alpha}+X_{\beta}\right)}
\end{aligned}
$$

where $X_{\alpha}$ и $X_{\beta}$ are the amount of $\alpha$ and $\beta$-phase, correspondingly, and $U_{\beta}$ is the relative content of $\boldsymbol{\beta}$ 
phase in the overall crystalline structure of the sample.

\subsection{Wide angle X-ray diffraction (WAXD) measurements}

The WAXD experiments were conducted with Rigaku Ultima IV powder X-ray diffractometer. $\mathrm{Cu}$ Ka radiation was used as a radiation source obtained from a generator set at $40 \mathrm{kV}$ and a current of $40 \mathrm{~mA}$. The scanning range was $5-40^{\circ}$ for the polymer samples and $5-65^{\circ}$ for pimelates, with a scan rate of $2 \% \mathrm{~min}$. The content of the $\beta$-phase ( $k$-value) of iPP was determined according to standard procedures described in the literature [51], using the equation:

$$
k=\frac{H_{\beta}(300)}{H_{\beta}(300)+H_{\alpha}(110)+H_{\alpha}(040)+H_{\alpha}(130)}
$$

where $H_{\alpha}(\mathrm{hkl})$ and $H_{\beta}(\mathrm{hkl})$ denotes the intensity of respective (hkl) peak belong to phase $\beta$ or $\alpha$.

\subsection{Fourier transform infrared (FT-IR) measurements}

The FT-IR spectra were recorded at different temperatures (starting from room temperature up to $250{ }^{\circ} \mathrm{C}$ ) using pressed $\mathrm{KBr}$ discs. The infrared spectra were recorded using a Perkin-Elmer System 2000 infrared interferometer. The variabletemperature cell P/N 21525 (Graseby Specac) with $\mathrm{KBr}$ windows was used for the high-temperature measurements. For a good signal-to noise ratio, 32 scans were collected and averaged. The resolution of the instrument was $4 \mathrm{~cm}^{-1}$. GRAMS ANALYST [52] and GRAMS 32 [53] software packages were used for spectra acquisition and management.

\subsection{Thermogravimetric analysis (TGA/DTG)}

Thermogravimetry of the synthesized pimelates was performed in the temperature range between 30 and $600{ }^{\circ} \mathrm{C}$ under inert $\left(\mathrm{N}_{2}\right)$ atmosphere with scanning rate of $5 \mathrm{~K} \mathrm{~min}^{-1}$, using Pyris Perkin Elmer Dyamond TGA/DTG system. The experiments were performed in ceramic pans with sample material around $7 \mathrm{mg}$.

\section{RESULTS AND DISCUSSION}

\subsection{Characterization of the synthesized pimelates}

The room temperature FT-IR spectra of the four investigated compounds are given in Figure 1. One broad band appears in all spectra under 3700 $\mathrm{cm}^{-1}$, which can be attributed to the stretching vi- brations of the water molecules. At the same time, a low intensity band is observed at around 1600 $\mathrm{cm}^{-1}$ that is due to the $\mathrm{HOH}$ bending modes.

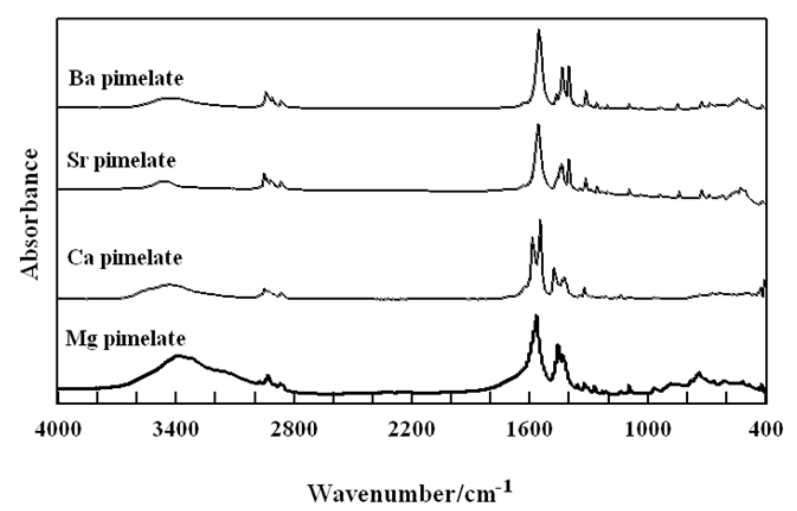

Fig. 1. Infrared spectra of the synthesized pimelates

This observation implies that all studied pimelates are crystallohydrates, which is in accordance with the determined crystal structures of barium and strontium pimelate [42-44]. In the region of the antisymmetric stretching modes of $\mathrm{COO}$ groups in the IR spectra of barium, strontium and magnesium pimelate, one band appears at 1550, 1552 and $1562 \mathrm{~cm}^{-1}$ respectively, whereas two bands are observed at 1580 and $1542 \mathrm{~cm}^{-1}$ in the spectrum of the calcium analogue. In the region of symmetric stretching modes of COO groups, in the spectra of barium and strontium pimelate bands at around 1460, 1430 and $1395 \mathrm{~cm}^{-1}$ appear, and the corresponding bands in the spectrum of calcium pimelate are found at 1471,1434 and $1420 \mathrm{~cm}^{-1}$. These bands appear at 1470, 1450 and $1425 \mathrm{~cm}^{-1}$ in the spectrum of magnesium pimelate. It should be beared in mind that bands from the scissoring modes of $\mathrm{CH}_{2}$ groups also appear in this spectral region. As can be seen, the intensity ratio between these three bands in the region from 1490 and 1380 $\mathrm{cm}^{-1}$ differs between the studied pimelates. Following the position of the bands, the lowest frequency band could with certainty be assigned to symmetric stretching modes of $\mathrm{COO}$ goups, whereas for the other two bands it is difficult to say which one is due to $\mathrm{CH}_{2}$ deformation modes, and which is related to $v_{\mathrm{s}}(\mathrm{COO})$ vibrations. In many previously published papers [54-57] attempts have been made to correlate the position and frequency difference between the stretching symmetric and stretching antisymmetric vibration of the $\mathrm{COO}$ group, on one hand, and the type of coordination of the carboxylic anions, on the other. It is known that the coordination of carboxylic ions to metals can be of several types: ionic, unidentate, chelate and bridge. It is usually assumed $[56,57]$ that at uni- 
dentate carboxylate ions, the frequency of the antisymmetric mode should be higher, and the one of the symmetric mode lower compared to the one of the ionic salt. The difference between these two frequencies $(\Delta v)$ should be higher with the higher strength of the $\mathrm{M}-\mathrm{O}$ bond. At unidentate complexes $\Delta v$ should be much greater than in the ionic complexes, whereas at chelating (bidentate) complexes this difference is significantly less than in the ionic compounds. On the other hand, if a carboxyl group is present as a bridging ligand, $\Delta v$ is greater than in chelating (bidentate) ligand and is close to the values for ionic compounds. But, one should also consider that these criteria are not always strict and should be critically observed. Based on the difference between the frequencies of the antisymmetric and symmetric $\mathrm{COO}$ strechings modes Li et al. [58] concluded that chelate coordination exists between the calcium ion and carbonyl groups in calcium pimelate. Following this model, it is implied that in the structure of magnesium pimelate, a chelate coordination of carboxylate groups exists. The difference between the frequencies of the two stretching vibrations of the $\mathrm{COO}$ groups is not big, i.e. it is $137 \mathrm{~cm}^{-1}$. This difference in the IR spectra of barium and strontium pimelate is $155 \mathrm{~cm}^{-1}$ (taking the frequency of the stretching symmetric COO mode as $1395 \mathrm{~cm}^{-1}$ ) and is close to the values found in the spectra of calcium pimelate $(\Delta v=160$ [58]) and magnesium pimelate. On the other hand, in the structure of barium and strontium pimelates [42-44] it was found that the coordination mode of carboxylate groups is bridging tridentate. As can be seen from the data, $\Delta v$ has similar values for all studied pimelates, but the conclusions for the coordination type of the carboxylate groups are different. Again, this suggests that one should always be careful when drawing conclusions based solely on the $\Delta v$ values in carboxylate complexes.

The fabrication of iPP-based products usually proceeds in nonisothermal conditions, starting with melting of the polymer and then continuing with gradual cooling, during which the polymer crystallizes. Keeping this in mind, it was of interest to follow the thermal behavior of the synthesized pimelates as potential nucleators in a temperature range, applied in real fabrication processes for iPP.

Thermogravimetric analyses of the samples in inert atmosphere are shown in Figure 2. It is evident that the weight loss started at temperature even slightly below $100{ }^{\circ} \mathrm{C}$, and the maximum weight loss rate, in the range from $108{ }^{\circ} \mathrm{C}$ to 180 ${ }^{\circ} \mathrm{C}$ (see Fig. 3 and Table 1), is different for all salts. It is likely that Ca-pimelate is the most thermally stable salt, and the stability is decreasing in order $\mathrm{Sr}, \mathrm{Ba}, \mathrm{Mg}$-pimelate.

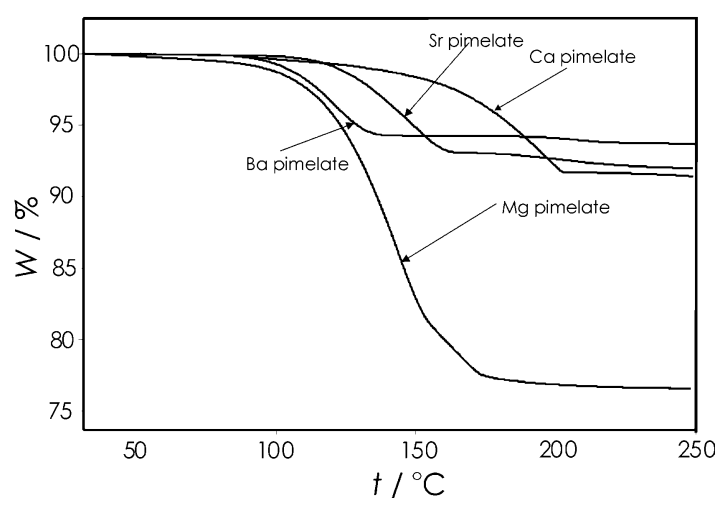

Fig. 2. TG-curves of the synthesized pimelates in inert atmosphere

In the investigated temperature region, decomposition of the pimelic anion is not expected, and hence the weight losses should be assigned to water evaporation from the crystallohydrates. The predicted number of water molecules in crystallohydrates $(n)$ is in good correlation with the amount of water detected as weight loss in TG-curve (W, $\%)$ and with water percentage in the predicted formulae of crystallohydrates $\left(W_{\mathrm{H} 20}, \%\right)$ (see Table 1$)$.

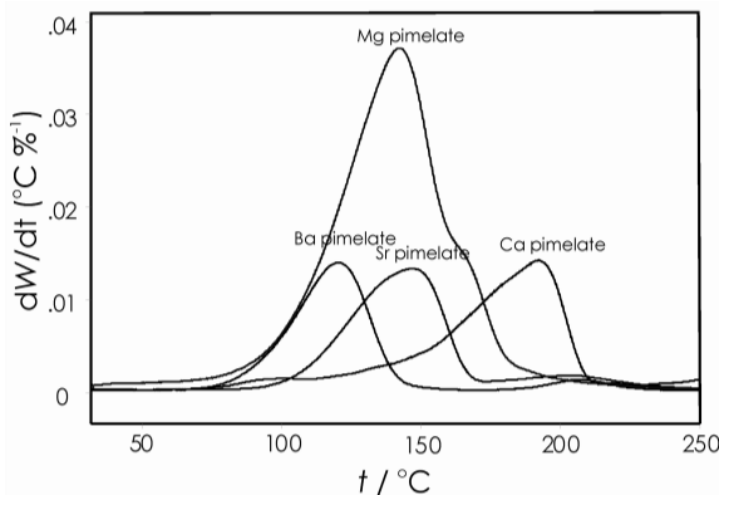

Fig. 3. DTG curves obtained from TGA of the synthesized pimelates

Table 1

Temperature of maximum weight loss rate ( $t)$, weight loss at $250{ }^{\circ} \mathrm{C}(\mathrm{W}, \%)$, predicted number of water molecules in crystallohydrates $\left(n_{\mathrm{H} 2 \mathrm{O}}\right)$ and water content in the predicted formulae $\left(W_{\mathrm{H} 2 \mathrm{O}}, \%\right)$

\begin{tabular}{lllll}
\hline \hline Compound & $t /{ }^{\circ} \mathrm{C}$ & $W / \%$ & $n_{\mathrm{H} 2 \mathrm{O}}$ & $W_{\mathrm{H} 2 \mathrm{O}} / \%$ \\
\hline Ba pimelate & 108.2 & 6.3 & 1 & 5.4 \\
Sr pimelate & 138.8 & 8.2 & 1 & 6.5 \\
Ca pimelate & 183.4 & 8.5 & 1 & 8.1 \\
Mg pimelate & 123.7 & 23.5 & 3 & 26.3 \\
\hline \hline
\end{tabular}


The X-ray diffractograms of the studied pimelates are given in Figure 4. A common pattern in the XRD patterns of all pimelates is the appearance of the most intensive peak at the lowest diffraction angles. Their intensity imply that atoms with the highest scattering factor are positioned on that crystallographic plane, which in this case are the cations. The cations are surrounded by $\mathrm{COO}^{-}$ anions forming a zone, layer that is polar: between two polar zones are situated the five $\mathrm{CH}_{2}$-groups from the pimelic acid, i.e. the acidic anions are spread linearly between the two polar zones. They are parallel to each other and form the non-polar zone (layer). The distance between the polar zones can be calculated (Table 2) and it decreases when going from barium to calcium, which is in accordance with the expected behavior (having in mind ionic radii). In the XRD pattern of magnesium pimelate this peak appears at the highest distances (lowest $2 \theta$ values) suggesting that $\mathrm{Mg}^{2+}$ is most voluminous in spite of having the smallest ionic radius. The reason for this could be found in the higher coordination number of magnesium ions for water molecules. In that way this associate would act as a larger structural unit, which is in accordance with the TGA results showing the highest mass loss in Mg pimelate (Table 1).

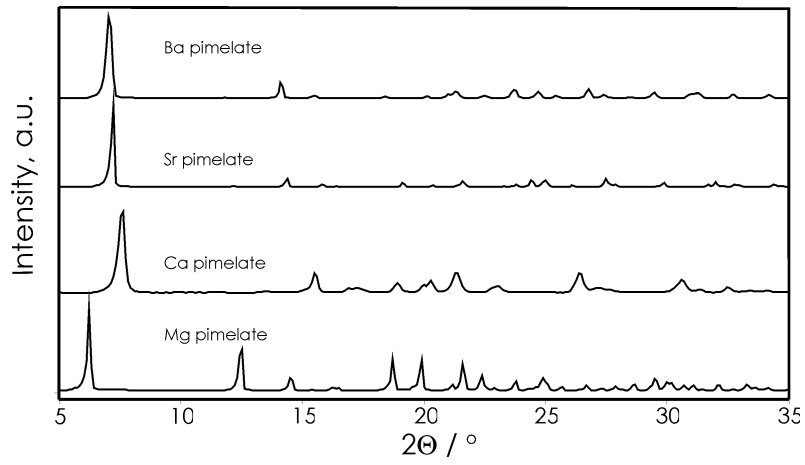

Fig. 4. Scattered X-ray intensities of the synthesized pimelates

\section{Table 2}

\section{Distances and changes in the structure calculated from the XRD patterns of the crystallohydrates} and the corresponding anhydrous $\mathrm{Ba}, \mathrm{Sr}, \mathrm{Ca}$ and $\mathrm{Mg}$ pimelates

\begin{tabular}{llll|lll}
\hline \hline \multirow{2}{*}{ Compound } & \multicolumn{3}{c|}{ Crystallohydrate } & \multicolumn{3}{c}{ Anhydrous } \\
\cline { 2 - 7 } & $d_{\text {(polar) }} / \AA$ & $a / \AA$ & $f_{\mathrm{m}}$ & $d_{\text {(polar) }} / \AA$ & $\Delta d_{\text {(polar) }} / \AA$ & $\Delta d_{(\text {polar) }} / \%$ \\
\hline Ba pimelate & 12.63 & 8.77 & 25.8 & 11.02 & 1.61 & 12.74 \\
Sr pimelate & 12.57 & 8.55 & 23.97 & 11.43 & 1.14 & 9.07 \\
Ca pimelate & 11.73 & $7.68^{*}$ & 15.36 & 11.14 & 0.59 & 5.03 \\
Mg pimelate & 14.26 & $/$ & $/$ & 10.47 & 3.79 & 26.58 \\
\hline \hline
\end{tabular}

*Assumed similar structural features with $\mathrm{Ba}$ and $\mathrm{Sr}$ pimelate

The XRD patterns of strontium and barium pimelate are very similar as shown in their recently published structures, according to which they crystallize in the monoclinic crystal system and are isotypic [42-44]. These findings suggest the existence of structural features in all investigated pimelates that are similar to the ones in $\mathrm{Ba}$ and $\mathrm{Sr}$ pimelate where the five $\mathrm{CH}_{2}$-groups from the pimelic acid connect the ionic zones composed of $\mathrm{COO}^{-}$and $\mathrm{M}^{2+}$ coordinated with $\mathrm{H}_{2} \mathrm{O}$ molecules [42-44]. Of course, one should bear in mind that the structures of $\mathrm{Ca}$ and $\mathrm{Mg}$ pimelate are not solved and the number and type of coordination of the water molecules can be different.

When studying the diffractogram of calcium pimelate a peak is observed at $2 \theta=13.5^{\circ}$ that in barium and strontium pimelate is identified as 110 (Fig. 4). This peak and the peaks at 7.5 and $15.5^{\circ}$ (see Fig. 4), in the diffractograms of barium and strontium pimelate identified as $020\left(7.1\right.$ and $7.2^{\circ}$, respectively) and $040\left(14.2^{\circ}\right.$ and $14.3^{\circ}$, respectively), suggest that this compound has similar structural features with barium and strontium pimelate. Following this assumption, a periodicity of around $7.68 \AA$ is calculated in the direction perpendicular to the $\mathrm{CH}_{2}$-groups in this pimelate, i.e. along the non-polar zone.

\subsection{Characterization of the pimelates upon heating}

In order to monitor the changes upon heating of the studied pimelates, FT-IR spectra were recorded of samples heated to $200{ }^{\circ} \mathrm{C}$. As can be seen from the IR spectra of these samples (Fig. 5), there are significant differences in the appearance of spectra of the corresponding samples at room and at high temperature in the region of the stretching vibrations of the carboxylate groups from around 
1600 to $1350 \mathrm{~cm}^{-1}$. In the spectra of the isotypic barium and strontium pimelate recorded at room temperature one band is observed at around 1550 $\mathrm{cm}^{-1}$ whereas in the spectrum of the corresponding samples obtained after heating at $200{ }^{\circ} \mathrm{C}$ at least two bands appear at around 1575 and $1520 \mathrm{~cm}^{-1}$ that could be attributed to antisymmetric streching modes of $\mathrm{COO}$ groups. In the spectrum of the heated sample of calcium pimelate, one intensive band appears at $1560 \mathrm{~cm}^{-1}$ instead of two at 1580 and $1542 \mathrm{~cm}^{-1}$ observed in the spectrum at room temperature. In the spectrum of the heated sample of magnesium pimelate, one intensive band is found at $1590 \mathrm{~cm}^{-1}$. At the same time, in the region of the $v_{\mathrm{s}}(\mathrm{COO})$ vibrations $\left(1480-1350 \mathrm{~cm}^{-1}\right)$, the three well separated bands observed in the spectra recorded at room temperature merge into one broad complex band with several submaxima in the spectra of the heated samples. This implies that significant changes occur upon heating the samples of the studied pimelates that affect the structure and the coordination mode of the carboxylate groups and consequently their stretching vibrations.

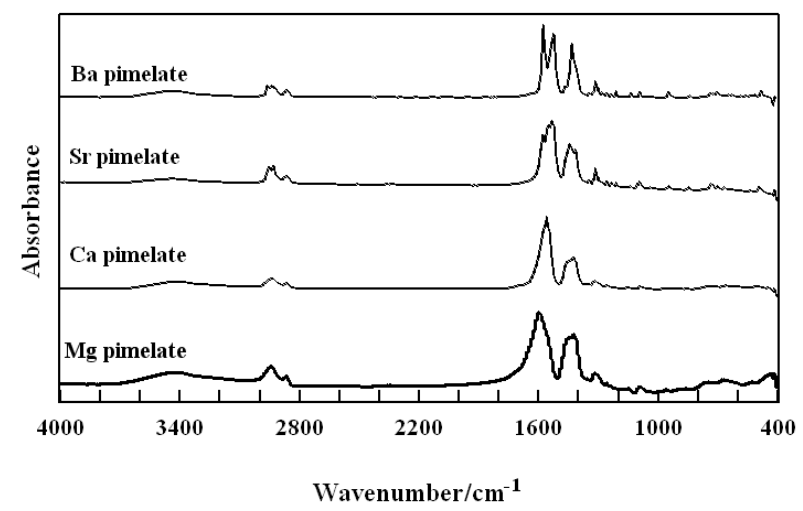

Fig. 5. Infrared spectra of the synthesized pimelates recorded after treatment at $200{ }^{\circ} \mathrm{C}$

Comparison of the XRD patterns of pimelates recorded at room temperature and the ones of the heated samples reveals that the anhydrous barium and strontium pimelate are crystalline substances with crystal structures that differ from the ones of their crystallohydrates. On the other hand, in the anhydrous calcium and magnesium pimelate, according to their XRD patterns, the degree of order in their structure is obviously lower (Fig. 6), or these substances are mostly amorphous.

An intensive band is observed in the diffractograms of the anhydrous pimelates in the region of $2 \theta$ between $7.7^{\circ}$ and $8.4^{\circ}$ suggesting existence of polar layers in their structures that are composed of atoms with higher X-ray scattering factors. The aliphatic zones consisting of the $\mathrm{CH}_{2}$-gropus of the pimelic acid are situated between these zones.

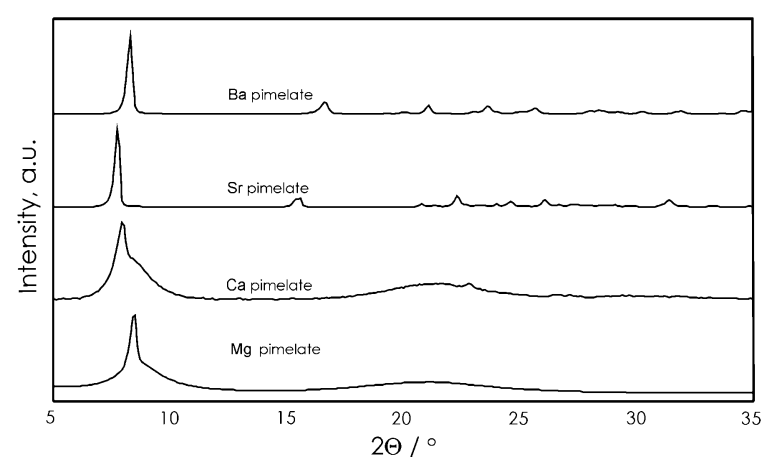

Fig. 6. Scattered $\mathrm{X}$-ray intensities of the synthesized pimelates recorded after treatment at $200{ }^{\circ} \mathrm{C}$

Upon losing water molecules, the peak characteristic for the planes where the cations are situated is shifted to higher diffraction angles, i.e. to smaller distances. The biggest shift is observed for magnesium pimelate, where the magnesium cation is surrounded with highest number of water molecules and the most notable change happens to the cation associate. The distances and changes upon losing water molecules are given in Table 2.

In spite of being amorphous, the pimelates of $\mathrm{Ca}$ and $\mathrm{Mg}$ show some degree of order that effects in one intensive peak at 7.9 and $7.7^{\circ}$ and one broader peak at $21^{\circ}$.

The expression proposed by Masuda [59] $\Delta 2 \theta / 2 \theta$ was employed as a measure for the degree of order suggesting that substances that have $\Delta 2 \theta / 2 \theta<0.2$ should be considered as crystalline. The differences between lower diffraction angles were smaller, with $\Delta 2 \theta / 2 \theta$ values 0.11 and 0.04 for $\mathrm{Ca}$ and $\mathrm{Mg}$ pimelate, whereas for the broader peak at around $21^{\circ}$ these values are 0.21 and 0.25 , respectively. This result implies the existence of a periodical arrangement of the polar and non-polar zones in these pimelates, even though the order is not as perfect as in the other two pimelates. In the anhydrous calcium pimelate peaks with low intensity appear above $22^{\circ}$, which means that in this case there is also some order on smaller distances.

For the degree of decrease of the other distances in the crystal lattices there is not much to discuss without having the solved crystal structures of the anhydrous $\mathrm{Ba}$ and $\mathrm{Sr}$ pimelates. Nevertheless, it is in accord to expect change in the distances as result of water loss, especially in the direction of the $a$-axis, having in mind that the water molecules are mainly located in that direction [42-44]. Such decrease is expected in the other two pimelates, as well. 


\subsection{Crystallization of nucleated polymer and correlation to the structure of pimelates}

The melting thermograms of the nucleated iPP reveal that all pimelates exhibit $\beta$-nucleation activity (Fig. 7), which is in accordance with literature data $[25,58,29]$.

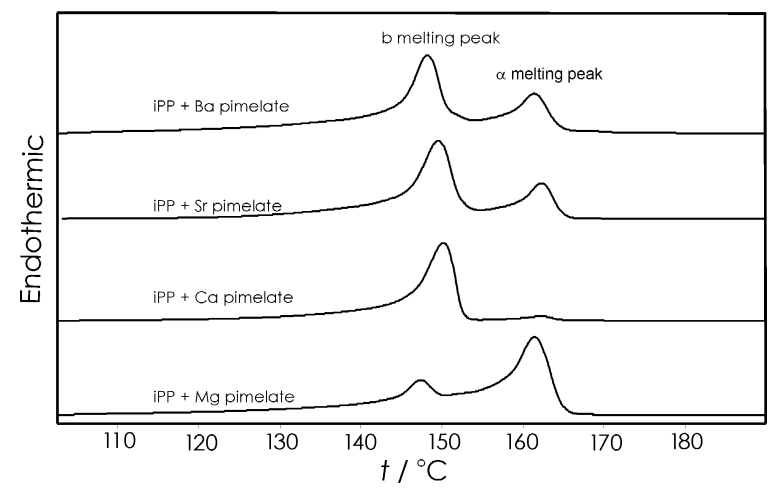

Fig. 7. Melting thermograms of iPP nucleated with different pimelates in non-isothermal crystallization with

$$
V_{c}=10 \mathrm{~K} \mathrm{~min}^{-1}
$$

We have tried to evaluate the nucleation activity by determination of the content of the $\beta$-phase in the crystal phase of iPP since $U_{\beta}$, in certain conditions, depends only on the character of the nucleating agent. For that purpose, the crystallization of the nucleated iPP was followed in non-isothermal conditions and then the content of the $\beta$-phase $\left(U_{\beta}\right)$ was calculated from the melting thermograms according to the method $[49,50]$, which has also been used in our previous study [29].

The dependence of the quantity of the $\beta$-phase on the cooling rate of the melted polymer is given in Figure 8 . The abundance of the two phases of polypropylene, alpha and beta, is obviously different for the different pimelates tested (Figs. 8 and 9)

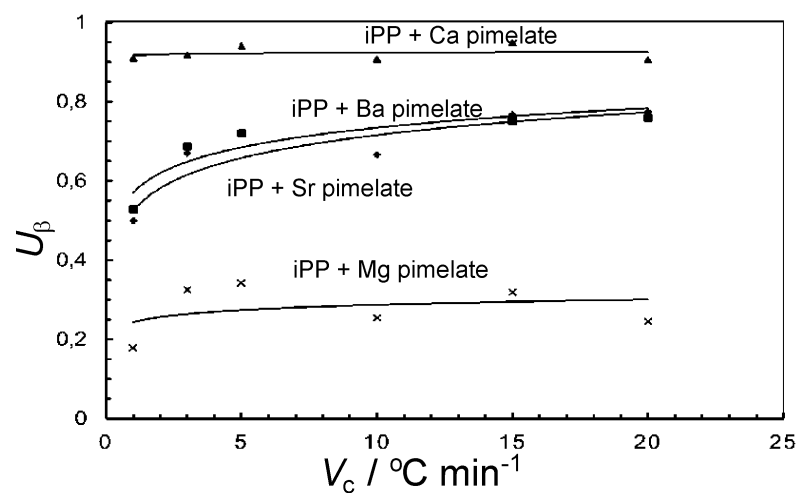

Fig. 8. Dependence of the content of the $\beta$ iPP polymorph modification $\left(U_{\beta}\right)$ on the cooling rate $\left(V_{\mathrm{c}}\right)$ in iPP nucleated with $0.1 \%(\mathrm{~m} / \mathrm{m})$ pimelate
The highest content of the $\beta$-crystal phase was found in the polypropylene nucleated with calcium pimelate $(0.91-0.94)$ and it is rather independent on the cooling rate. The lowest $\beta$-phase content was found in the polymer nucleated with magnesium pimelate ranging from 0.18 to 0.34 depending on the cooling rate. It is interesting to record the experimental evidence that, in all studied systems except the one nucleated with calcium pimelate, the content of the $\beta$-phase in the polymer increases with the increasing of the cooling rate. The XRD patterns of iPP and iPP nucleated with the different pimelates are shown in Figure 9. The characteristic peaks for the $\beta$-phase appear in all nucleated samples and their intensity and intensity ratios, as can be seen, are obviously very well correlated to the results obtained by DSC. The most intensive peaks are observed for iPP nucleated with $\mathrm{Ca}$ pimelate, whereas the lowest intensity is seen for iPP nucleated with Mg pimelate. The calculated values for $K_{\beta}$ are as follows: 0.073 for iPP nucleated with $\mathrm{Mg}$ pimelate, 0.584 and 0.488 for the polymers nucleated with $\mathrm{Ba}$ and $\mathrm{Sr}$ pimelates, and 0.782 for the polymer nucleated with $\mathrm{Ca}$ pimelate.

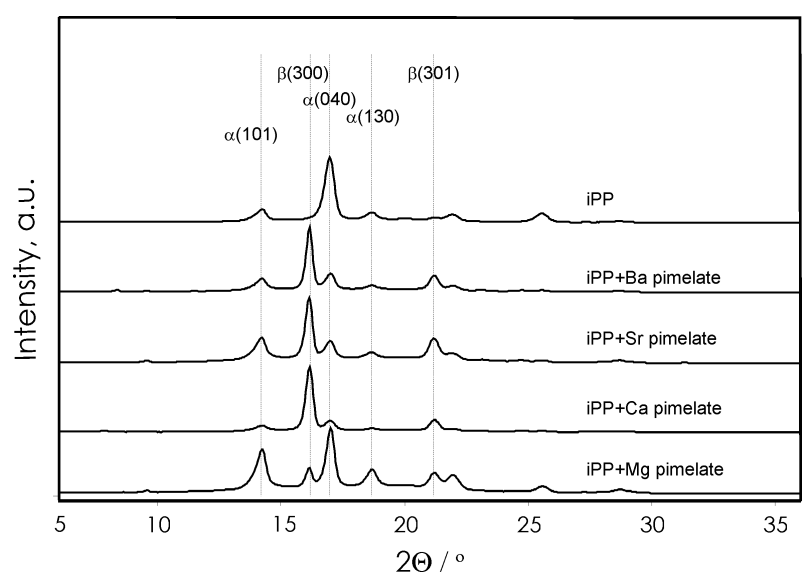

Fig. 9. Scattered X-ray intensities of iPP and iPP nucleated with the corresponding pimelates

According to the "dimensional lattice matching theory" the $\beta$-nucleation capacity is a result of coincidence of certain crystallographic distances in the structure of the nucleation agent and the $\beta$-phase of iPP. Actually, this distance should be located on the contact surface of the nucleation agent and it should be equal to the dimensions of the $c$-axis of the $\beta$-phase (6.5 $\AA$ ), i.e. the periodicity along the iPP chain. In such case, the growth of the polymorph crystal modification of the polymer is induced actually by the nucleating agent's surface. This phenomenon is called epi- 
taxy. In general, epitaxy is defined as the growth of one crystalline phase (here, the polymer, iPP) on the surface of a crystal of another phase (here, the substrate - nucleator) in one or more strictly defined crystallographic orientations [3, 8].

According to Kawai et al. [37], growth of the polymer on the surface of a given substrate can occur even in the case when there is no exact match between the crystallographic distances. A so-called misfit factor $\left(f_{\mathrm{m}}\right)$ between the two crystal structures (the $\beta$-structure and the substrate) has suggested that it is given with the following expression:

$$
f_{m}=\frac{P_{B}-P_{A}}{P_{A}} \times 100
$$

where $P_{A}$ and $P_{B}$ are the corresponding periodic distances of the substrate and the polymer, and if $f_{\mathrm{m}}<15 \%$, an epitaxial growth can be expected from the substrate surface.

Considering the structure of the pimelate crystallohydrates, it is expected that the periodicity, which is 8.77 and $8.55 \AA$ in the direction perpendicular to the $\mathrm{CH}_{2}$-groups (along the $a$-axis), for the barium and strontium pimelates is most suitable for deposition of the $3_{1} \mathrm{iPP}$ helicoidal iPP molecule. The misfit factors for $\mathrm{Ba}$ and $\mathrm{Sr}$ pimelates (Table 2) are higher than $15 \%$ and are therefore not suitable for epitaxial growth. But, upon losing water, the distances in the crystal lattice decrease (Table 2) causing decrease in $f_{\mathrm{m}}$ and its value falling in the range below 15\% [37], which makes possible the growth of the crystals of the $\beta$-phase of iPP on the surface of these pimelates. Hence, these pimelates, according to the quantity of the $\beta$ phase induced upon crystallization of iPP, are good beta nucleators. Such a kind of nucleation activity is usually exhibited by nucleating agents with misfit factor lower than $15 \%$ [60].

The anhydrous calcium pimelate, which has a less ordered structure, is the best beta nucleator (see Figs. 8 and 9) with the content of the $\beta$-phase in the total crystalline phase above 0.9. Upon losing water the distances in the structure decrease (Table 2) followed by decrease of the degree of order. The periodicity (although not perfect) in the aliphatic zone, due to the smaller ionic radius of $\mathrm{Ca}$ compared to $\mathrm{Ba}$ and $\mathrm{Sr}$, is probably much closer to the one of $6.5 \AA$ and has a better match between the polymer $3_{1}$ helicoid and substrate surface.

In fact, the intermolecular interactions are crucial since the iPP molecule is affected by attractive and repulsive forces from the substrate surface. Periodicity of these fields is needed for effec- tive epitaxial growth. Evidently, this periodicity should not necessarily be ideal, which is confirmed by the nucleation activity of the amorphous pimelates. It is interesting to mention that under quiescent conditions crystalline polystyrene was found to selectively nucleate the $\beta$-iPP, while the amorphous polystyrene (where stacking of the aromatic rings with periodicity of $5.5 \AA$ ) was found to nucleate $\alpha$-iPP [61].

Magnesium pimelate has the lowest betanucleation activity. The XRD patterns reveal the biggest change and the lowest order in the crystal structure of the anhydrous pimelate. Due to the lowest ionic radius of $\mathrm{Mg}^{2+}$, the lowest periodicity is expected in the aliphatic zone of the structure of the anhydrous compound, even on distances smaller than $6.5 \AA$. On the other hand, it is well known that the beta polymorph modification of iPP is not nucleated on such short distances $[35,36,54]$.

\section{CONCLUSIONS}

The nucleation activity of $\mathrm{Ba}, \mathrm{Sr}, \mathrm{Ca}$ and $\mathrm{Mg}$ pimelates towards iPP has been compared based on the dimensional lattice matching theory of epitaxial polymer crystallization. As revealed by FTIR and XRD studies, the pimelates synthesized by reaction of pimelic acid and $\mathrm{Ba}, \mathrm{Sr}, \mathrm{Ca}$ and $\mathrm{Mg}$ carbonates are all crystallohydrates. Their thermal behavior has been analyzed by TGA in the temperature range characteristic for processing of iPP (above $200{ }^{\circ} \mathrm{C}$ ). Ca pimelate is the most thermally stable, whereas the stability of the other salts decreased in order $\mathrm{Sr}, \mathrm{Ba}, \mathrm{Mg}$, due to water evaporation from the crystallohydrates. The predicted number of water molecules in the structure of pimelates was in good correlation with the amount of water detected as weight loss in TGA. At the melting temperature of iPP, the pimelates of $\mathrm{Ba}$ and $\mathrm{Sr}$ are crystalline, whereas those of $\mathrm{Ca}$ and $\mathrm{Mg}$ are mostly amorphous. The amount of $\beta$-phase in iPP, induced by the pimelates during the nonisothermal crystallization of iPP differs considerably with regards to cooling rate, and the most efficient $\beta$-nucleator was the anhydrous $\mathrm{Ca}$ pimelate. $\mathrm{Ba}$ and $\mathrm{Sr}$ pimelates were shown to induce certain amount of $\beta$-phase in iPP, and their behavior as $\beta$-nucleators with respect to cooling rate was similar. The differences in $\beta$ nucleating efficiency of the pimelates are related to the changes in their structure upon heating, i.e. changes in the so called misfit factor that is responsible for epitaxial growth during the crystallization of the polymer on the surfaces of the nucleating agents. 


\section{REFERENCES}

[1] J. Varga, Supermolecular structure of isotactic polypropylene, J. Mater. Sci, 27, 2557-2573 (1992).

[2] M. Naiki, T. Kikawa, Y. Endo, K. Nozaki, T. Yamamoto, T. Hara, Crystal ordering of alpha phase isotactic polypropylene, Polymer, 42, 5471-54773 (2000).

[3] B. Lotz, J. C. Wittmann, A. J. Lovinger, Structure and morphology of poly(propylenes): A molecular analysis, Polymer, 37, 4979-4992 (1996).

[4] H. Awaya, Morphology of different types of isotactic polypropylene spherulites crystallized from melt, Polymer, 29, 591-596 (1988).

[5] D. L. Dorset, M. P. McCourt, S. Kopp; M. Schumacher, T. Okihara, B. Lotz, Isotactic polypropylene, $\beta$-phase: a study in frustration, Polymer, 39, 6331-6337 (1998).

[6] K. Busse, J. Kressler, R. D. Maier, J. Scherble, Tailoring of the alpha, beta, and gamma-modification in isotactic polypropene and propene/ethene random copolymers, Macromolecules, 33, 8775-8780 (2000).

[7] D. R. Norton, A. Keller, The spherulitic and lamellar morphology of melt-crystallized isotactic polypropylene, Polymer, 26, 704-716 (1985).

[8] B. Lotz, J. C. Wittmann, The molecular origin of lamellar branching in the $\alpha$ (monoclinic) form of isotactic polypropylene, J. Polym. Sci. Part B: Polym. Phys., 24 1541-1558 (1986)

[9] Z. G. Wang, R. A. Phillips, B. S. Hsiao, Morphology development during isothermal crystallization. I. Isotactic and atactic polypropylene blends, J. Polym. Sci. Part B: Polym. Phys., 38, 2580-2590 (2000).

[10] S. Bruckner, S. V. Meille, V. Petraccone, B. Pirozzi, Polymorphism in isotactic polypropylene, Prog. Polym. Sci., 16, 361-404 (1991).

[11] J. Varga, J. Karger-Kocsis, Rules of supermolecular structure formation in sheared isotactic polypropylene melts, J. Polym. Sci. Part B: Polymer Phys. Ed., 34, 657-670 (1996).

[12] R. H. Somani, B. S. Hsiao, A. Nogales, H. Fruitwala, S Srinivas, A. H. Tsou, Structure Development during Shear Flow Induced Crystallization of i-PP: In Situ Wide-Angle X-ray Diffraction Study, Macromolecules, 34, 5902-5909 (2001)

[13] Y. H. Chen, Y. M. Mao, Z. M. Li, B. S. Hsiao, Competitive Growth of $\alpha$ - and $\beta$-Crystals in $\beta$-Nucleated Isotactic Polypropylene under Shear Flow, Macromolecules, 43, 6760-6771 (2010).

[14] J. Varga, G. W. Ehrenstein, Formation of $\beta$-modification of isotactic polypropylene in its late stage of crystallization, Polymer, 37, 5959-5963 (1996).

[15] A. J. Lovinger, J. O. Chua, C. C. Gryte, Studies on the $\alpha$ and $\beta$ forms of isotactic polypropylene by crystallization in a temperature gradient, J. Polym. Sci. Polym. Phys. $E d ., 15,641-656$ (1977).

[16] J. Zhang, K. Shen, S. Na, Q. Fu, Vibration-induced change of crystal structure in isotactic polypropylene and its improved mechanical properties, J. Polym. Sci. Part. B: Polym. Phys., 42, 2385-2390 (2004).
[17] J. Varga, $\beta$-modification of isotactic polypropylene: preparation, structure, processing, properties, and application, J. Macromol. Sci. Part B: Phys., 41, 1121-1171 (2002).

[18] J. X. Li, W. L. Cheung, Conversion of growth and recrystallisation of $\beta$-phase in doped iPP, Polymer, 40, 2085-2088 (1999).

[19] C. Grein, Toughness of Neat Rubber Modified and Filled $\beta$-nucleated Polypropylene: From Fundamentals to Applications, Adv. Polym. Sci., 188, 43-104 (2005).

[20] R. Cermak, M. Obadal, P. Ponizil, M. Polaskova, K. Stoklasa, A. Lengalova, Injection-moulded $\alpha$ - and $\beta$ polypropylenes: I. Structure vs. processing parameters, Eur. Polym. J., 41, 1838-1845 (2006).

[21] J. Kotek, M. Raab, J. Baldrian, W. Grellmann, The effect of specific $\beta$-nucleation on morphology and mechanical behavior of isotactic polypropylene, J. Appl. Polym. Sci., 85 1174-1184 (2002).

[22] Q. Dou, Effect of Metallic Salts of Pimelic Acid and Crystallization Temperatures on the Formation of $\beta$ Crystalline Form in Isotactic Poly(propylene), J. Macromol. Sci. Part B: Phys., 46, 1063-1080 (2007).

[23] Q. Dou, A Comparison of the Effects of Calcium Glutarate and Pimelate on the Formation of $\beta$-Crystalline Form in Isotactic Poly(propylene), J. Macromol. Sci. Part B: Phys., 47, 127-138 (2008).

[24] J. Varga, I. Mudra, G. W. Ehrenstein, Crystallization and melting of $\beta$-nucleated isotactic Polypropylene, $J$. Therm. Anal. Cal., 56, 1047-1057 (1999).

[25] J. Varga, I. Mudra, G. W. Ehrenstein, Highly active thermally stable $\beta$-nucleating agents for isotactic polypropylene, J. Appl. Polym. Sci., 74, 2357-2368 (1999).

[26] J. Karger-Kocsis, E. Moos, I. Mudra, J. Varga, Effects of molecular weight on the perforation impact behavior of injection-molded plaques of $\alpha$ - and $\beta$-phase isotactic polypropylene, J. Macromol. Sci. Part B: Phys., 38, 647-662 (1999).

[27] G. J. Vancso, L. G. M. Beekmans, R. Pearce, D. Trifonova, J. Varga, From microns to nanometers: Morphology development in semicrystalline polymers by scanning force microscopy, J. Macromol. Sci. Part B: Phys., 38, 491-503 (1999).

[28] D. Trifonova, J. Varga, G. W. Ehrenstein, G. J. Vancso, Features of the hedritic morphology of $\beta$-isotactic polypropylene studied by atomic force microscopy, J. Polym. Sci. Part B: Polym. Phys., 38, 672-681 (2000).

[29] A. Janevski, G. Bogoeva-Gaceva, J. Serb. Chem. Soc. (2014), doi:10.2298/JSC140324055J

[30] Q. Dou, H. D. Li, Effect of Metallic Salts of Glutaric Acid on the Formation of $\beta$-crystalline Form in Isotactic Polypropylene, J. Elastomers and Plastics, 41, 509-522 (2009).

[31] J. Varga, Crystallization, Melting and Supermolecular Structure of Isotactic Polypropylene. in: J. KargerKocsis (Ed.), Polypropylene: Structure, Blends and Composites, Chapman \& Hall, London, Vol. 1, pp. 56115,1995

[32] J. C. Wittmann, B. Lotz, Epitaxial crystallization of polyethylene on organic substrates: A reappraisal of the 
mode of action of selected nucleating agents, J. Polym. Sci. Part B: Polym. Phys., 19, 1837-1851 (1981).

[33] J. C. Wittmann, B. Lotz, Epitaxial crystallization of polymers on organic and polymeric substrates, Prog. Polym. Sci., 15, 909-948 (1990).

[34] S. Yoshimoto, T. Ueda, K. Yamanaka, A. Kawaguchi, E. Tobita, T. Haruna, Epitaxial act of sodium 2,2'methylene-bis-(4,6-di-t-butylphenylene)phosphate on isotactic polypropylene, Polymer, 42, 9627-9631 (2001).

[35] V. Mathieu, A. Thierry, B. Lotz, J. C. Wittmann," Multiple" nucleation of the (010) contact face of isotactic polypropylene, $\alpha$ phase, Polymer, 41, 7241-72553 (2000).

[36] W. Stocker, M. Schumacher, S. Graff, Epitaxial Crystallization and AFM Investigation of a Frustrated Polymer Structure: Isotactic Poly(propylene), $\beta$ Phase, Macromolecules, 31, 807-814 (1998).

[37] T. Kawai, R. Iijima, Y. Yamamoto, T. Kimura, Crystal orientation of $\beta$-phase isotactic polypropylene induced by magnetic orientation of $N, N$-dicyclohexyl-2,6-naphthalene dicarboxamide, Polymer, 43, 7301-7306 (2002).

[38] H. G. Haubruge, R. Daussin, A. M. Jonas, R. Legras, J. C. Wittmann, B. Lotz, Epitaxial Nucleation of Poly(ethylene terephthalate) by Talc: Structure at the Lattice and Lamellar Scales, Macromolecules, 36, 44524456 (2003).

[39] S. Yan, S. Petermann, Nucleation and overgrowth of PE on PTFE/iPP interfaces, J. Polym. Sci. Part B: Polym. Phys., 38, 80-83 (2000).

[40] Y. Sun, H. Li, Y. Huang, E. Chen, Z. Gan, S. Yan, Epitaxial crystallization of poly(butylene adipate) on highly oriented isotactic polypropylene thin film, Polymer, $\mathbf{4 7}$, 2455-2459 (2006).

[41] Y. Shi, Z. Xin, The Correlation between Crystal Structure and Nucleation Efficiency of a Lithium (I) Complex on Isotactic Polypropylene, J. Appl. Polym. Sci., 125, 2963-2969 (2012).

[42] M. Grzesiak, A. Rafalska-Lasocha, W. Lasocha, Synthesis and XRPD studies of new barium dicarboxylates, Powder Diffraction., 26, 53-65 (2011).

[43] M. Grzesiak, W. Nitek, A. R. Lasocha, W. Lasocha, Investigations of new barium dicarboxylates, $Z$. Kristallogr., 227, 629-634 (2012).

[44] M. Grzesiak-Nowak, W. Nitek, A. Rafalska-Lasocha, W. Lasocha, Synthesis and investigations of new strontium dicarboxylates, Z. Kristallogr., 228, 590-597 (2013).

[45] G. Shi, B. Huang, J. Zhang, Enthalpy of fusion and equilibrium melting point of the $\beta$-form of polypropylene, Macromol. Chem. Rap. Comm., 5, 573-578 (1984).
[46] M. Avella, E. Martuscelli, C. Sellit, E. Garagnani, Crystallization behaviour and mechanical properties of polypropylene-based composites, J. Mater. Sci., 22, 31853193 (1987).

[47] B. Monasse, J. M. Haudin, Thermal dependence of nucleation and growth rate in polypropylene by non isothermal calorimetry, Coll. Polym. Sci., 264, 117-122 (1986).

[48] S. Brandup, E. H. Imergut, Polymer Handbook, Interscience, New York, USA, 1975, p. 24.

[49] M. R. Meng, Q. Dou, Effect of Filler Treatment on Crystallization, Morphology and Mechanical Properties of Polypropylene/Calcium Carbonate Composites, $J$. Macromol. Sci. Part B: Physics, 48, 213-225 (2009).

[50] M. Liu, B. Guo, M. Du, F. Chen, D. Jia, Halloysite nanotubes as a novel $\beta$-nucleating agent for isotactic polypropylene, Polymer, 50, 3022-3030 (2009).

[51] A. Turner-Jones, J. M. Aizlewood, D. R. Beckett, Crystalline forms of isotactic polypropylene, Macromol. Chem. Phys., 75, 134-158 (1964).

[52] GRAMS ANALYST ${ }^{\mathrm{TM}}$ for PE-2000 FT-IR, Version 3.01B Level II, Galactic Industries, 1994.

[53] GRAMS/32 Spectral Notebase, Version 4.10, Galactic Industries Corporation, 1996.

[54] F. A. Cotton, The infrared spectra of Transition Metal Complexes, in J. Lewis and R.G. Wilkins (Eds.), Modern Coordination Chemistry, Interscience, New York, 1960.

[55] Spectroscopic Properties of Inorganic and Organometallic Compounds, Specialist Periodical Reports, Chem. Soc., London, Vol. 1, p. 199, Vol. 2, p. 333, 1968, 1969.

[56] G. B. Deacon, R. J. Phillips, Relationships between the carbon-oxygen stretching frequencies of carboxylato complexes and the type of carboxylate coordination, Coord. Chem. Rev., 33, 227-250 (1980).

[57] K. Nakamoto, Infrared and Raman spectra of Inorganic and Coordination Compounds, Part B, Fifth Edition, Wiley, New York, p. 59, 2005.

[58] X. Li, K. Hu, M. Ji, Y. Huang, G. Zhou, Calcium dicarboxylates nucleation of $\beta$-polypropylene, J. Appl. Polym. Sci., 86, 633-638 (2002).

[59] T. Masuda, T. Takahashi, T. Higashimura, J. Chem. Soc., Chem. Commun., 1297-1298 (1982).

[60] Z. Guan, Z. Lin, K. Mai, Monetaria moneta as a novel $\beta$ nucleating agent for isotactic polypropylene, Compos. Sci. Technol., 87, 58-63 (2013)

[61] P. Andrew, W. Z. Peng, E. Graham, Polystyrene as a versatile nucleating agent for polypropylene, Polymer, 51, 1599-1607 (2010). 
